\title{
IS THERE A NON-LINEAR RELATIONSHIP BETWEEN TRADE AND GROWTH? A PANEL THRESHOLD ANALYSIS FOR CENTRAL AND EASTERN EUROPEAN COUNTRIES
}

\author{
Pelin Varol IYIDOĞAN - Başak DALGIÇ - Hale AKBULUT
}

(Received: 10 December 2015; revision received: 15 April 2016; accepted: 10 July 2016)

It is suggested that international trade has a positive effect on the growth rate of economies. Although a vast literature has illustrated that open or more liberalised economies grow faster, the specific factors that promote this process have only recently begun to be investigated. We belive that there is a non-linear relationship between trade and growth, with the impact depending on a number of macroeconomic factors, i.e. the magnitude and even the direction of the effect of trade on economic performance might depend on other macroeconomic variables. Within this framework, our study aims to investigate the possible non-linearity in the trade-growth relationship, with a special focus on the financial deepening level for the selected Central and Eastern European (CEE) countries. Unlike the existing empirical literature on trade-growth nexus for the CEE economies, we utilise threshold regression techniques, where we allow the size and direction of the impact of trade on growth to differ between regimes, conditioning on the financial deepening level of these countries. Regarding credit growth and investment/credit ratio as thresholds, the countries in the upper regime benefit significantly more from trade.

Keywords: growth, international trade, financial deepening, threshold models

JEL classification indices: F10, G20, O16

Pelin Varol İyidoğan, corresponding author. Associate Professor at the Department of Public Finance, Hacettepe University, Beytepe Campus, Ankara, Turkey. E-mail: pelinv@hacettepe.edu.tr

Başak Dalgıç, Associate Professor at the Department of Public Finance, Hacettepe University, Beytepe Campus, Ankara, Turkey. E-mail: basakcakar@hacettepe.edu.tr

Hale Akbulut, Research Assistant at the Department of Public Finance, Hacettepe University, Beytepe Campus, Ankara, Turkey. E-mail: halepehlivan@hacettepe.edu.tr 


\section{INTRODUCTION}

The transition from centrally planned economies to market economies, together with the efforts to join the EU, has led to significant effects in the legal, institutional, and economic structures of all Central and Eastern European (CEE) countries. Although there are some differences among countries as a consequence of the economic policies devoted to the reconstitution of the economies through reforms, CEE economies have exhibited a growth performance of above $5 \%$ on average in the last decade (excluding the 2008 global crisis period).

Within the vast literature that addresses the underlying factors for the growth performance of CEE economies, an analysis of international trade that has been one of the fundamental constituents of the reform process plays an important role. The liberalisation of trade has been triggered by the collapse of the Council of Mutual Economic Assistance (CMEA), which imposed strict trade policies in CEE countries. As stated by Michalopoulos (2001) and Halpern (2013), CMEA created distortions since it placed uncompetitive state controlled firms and sectors onto the world markets, depending on a centrally administered price system that broke the incentives to transfer new technologies and produce higher quality output. In the aftermath of the breakdown in the CMEA arrangements, the trade structure of the firms operating under market conditions without restrictions has shifted from the former trade integration area to the rest of the world, particularly to the EU. In addition to the transformation of the central planning system, the EU accession process has also caused a rise in the trade volume of CEE economies.

Expanding international trade, which has triggered technology transfer through imports of intermediate and investment goods and transmission of knowledge via exports, contributed to the structural changes in these economies. Accordingly, as growth depends not only on the factors of production, but also on technological improvements, the effect of trade on growth becomes a prominent issue on which light has to be shed.

Within this framework, our study aims to examine the relationship between international trade and growth for the selected CEE economies, in an effort to examine whether variables that work well in large cross-country regressions can help explain CEE countries' economic performance, as well as to investigate the possible non-linearities. We pay special attention to financial deepening by assuming that this determines the size and direction of the impact of trade on growth. Previous literature also mentions the positive role of financial deepening. As Levine (2005) states, financial institutions and markets accelerate economic growth by easing the exchange of goods and services through the provision of payment services. Moreover, Fries et al. (2006) and Caporale et al. (2015) suggest that the improvement of efficiency of the financial sector, which could be attributed to the 
banking reforms, the entry of foreign banks, and the privatisation of state-owned banks, has promoted growth through a reduction in transaction costs and an increase in credit availability for trade and other activities.

Our study covers Bulgaria, Croatia, the Czech Republic, Estonia, Hungary, Latvia, Lithuania, Poland, Romania, the Slovak Republic, and Slovenia over the period of 1995-2012. Unlike the existing empirical literature on the trade-growth nexus for CEE economies, we employ threshold regression techniques. In particular, we allow the size and direction of the impact of international trade on growth differ between regimes, conditioning on the financial deepening level of the countries. Namely, we analyse the effect of exports, imports, and trade openness together with the variables representing financial deepening level, i.e. broad money, claims on the private sector, domestic credit growth, and investment to credit ratio on trade-growth interaction. From this point forth, our study makes an important contribution to the existing literature by considering the threshold effects of the financial deepening indicators in international trade-growth relationship.

The remainder of the paper is organised as follows: Section 2 provides a brief review of the relevant literature. Section 3 presents the data and methodology. Section 4 discusses the empirical results. Section 5 concludes.

\section{LITERATURE REVIEW}

Multilateral institutions such as the IMF, the World Bank, and the OECD usually advise countries to increase trade in order to achieve productivity improvements and growth: this view is also supported by economic theory. First, international trade leads to a more efficient use of a country's resources through the import of goods and services that are otherwise too costly to produce within the country. According to this view, which is based on the law of Ricardo's comparative advantage (1951[1817]), all countries will benefit from international trade, even if one of them has absolute advantage in all goods. Moreover, the endogenous growth theory suggests that opening up to trade can increase the rate of technological progress, hence productivity growth, through an expansion of the market for either output or input (Dowrick - Golley 2004). De Loecker (2007) also confirms the positive effects of exporting on productivity levels. He uses data on Slovenian manufacturing firms and concludes that starting to export leads to more productivity.

Economists also suggest that the acceleration in exports, imports of intermediate inputs, and foreign direct investments (FDI), prompted by trade policy openness, would lead to technological spillovers (Salinas - Aksoy 2006). Further- 
more, as suppliers are faced with more competition, they will be more willing to follow technological innovations in order to survive. Therefore, the nature of economic agents will automatically serve the impact of international trade on economic growth. International trade will thus positively affect per capita income and growth through the diffusion of knowledge and technology, ${ }^{1}$ or FDI and market size increases that allow for economies of scale (Leyaro - Morrissey 2010). Acemoğlu (2007) further emphasises that international trade enriches the process of technology diffusion, since it allows for the process of the "international product cycle", whereby technology diffusion goes hand-in-hand with certain products previously produced by technologically advanced economies migrating to less developed nations. In other words, international trade can create spillovers through demonstration effects when domestic firms learn the innovative content of imported goods.

Thirlwall (2000) suggests that theories that point out the advantages of increasing trade identify two types of gains: static and dynamic gains. Accordingly, static gains arise from the reallocation of resources from one sector to another based on comparative advantage, whereas dynamic gains arise when international trade leads to increases in investments and faster productivity growth based on scale economies, learning-by-doing effects.

Regarding the openness of trade, Dowrick - Golley (2004) distinguish between two concepts, i.e. "revealed openness" and "policy openness". While revealed openness is the ratio of total international trade to GDP, the measurement of policy openness is fraught with difficulties. Pritchett (1996) emphasises that the most commonly used measures are uncorrelated with each other, highlighting the difficulty of finding a reliable measure of policy openness: nevertheless, studies use both types of indicators. Some previous studies that use policy indicators are Edwards (1998), Greenaway et al. (2002), and Salinas - Aksoy (2006). Edwards (1998) employs different types of indices in order to measure openness for 93 advanced and developing countries. He observed a positive relationship between openness and economic growth for all indices. Similarly, Greenaway et al. (2002) find a positive relationship between trade openness and growth for three different indicators derived from Sachs - Warner (1995), Dean et al. (1994), and the World Bank (1993).

There are also studies using the concept of revealed openness or the ratio of exports to GDP in particular. For instance, Dowrick - Golley (2004) find empirical evidence in favour of the positive growth effects of trade for 127 countries. In addition, they suggest that the benefits of trade openness are greater for less

For a more detailed information about knowledge spillovers and their interaction with agglomeration economies, see Popescu (2015a, 2015b) and Nica (2015). 
developed economies than for advanced economies. Dufrenot et al. (2010) suggest that after conditioning the robust growth determinants, trade has a greater impact on growth among low-growth countries relative to that of high-growth economies.

A few studies examine the relationship between trade and economic growth for CEE countries. Awokuse (2007) investigated the effects of exports and imports on economic growth in Bulgaria, the Czech Republic and Poland. While growth in Bulgaria was found to be export-led, growth in Poland was found to be import-led. Furthermore, their results indicated that both exports and imports influenced economic growth in the Czech Republic.

Carp - Popa (2013) analysed the relationship between exports and GDP in the case of Romania and Bulgaria and found that the impact of exports on the national volume of GDP was insignificant. The underlying reasons for this finding were identified as a lack of transparency in the national market, corruption and the deficiency of the justice system.

Fitzova - Zidek (2015) examined the same relationship in the Czech and Slovak Republics by using a VAR approach. The effects of trade were observed to be significant; they therefore conclude that economic growth in both countries is export-led.

Mikulic - Nagyszombaty (2015) tested whether international trade was a key determinant of the regional convergence process in Croatia. However, their panel data model results suggested that international trade was not the dominant factor promoting the convergence of Croatian regions.

Some studies deal with the possible non-linearity by using threshold regression techniques. In one of these studies, Foster (2006) employed initial GDP per capita and the growth rate of exports as threshold variables to examine the relationship between exports and growth in African countries. His results suggested that it was not necessary for a country to have a certain level of development or to have an export base to benefit from exporting. Wacziarg - Welch (2008) used the investment rate as a threshold variable and suggested that trade liberalisation fosters growth, in part through its effect on physical capital accumulation.

Leyaro - Morrissey (2010) examine the relationship between trade openness and growth for 135 developing countries and find that although trade openness promotes growth, this effect in developing countries is limited by the significance of some structural variables. Khoury - Savvides (2006) find evidence of a positive and significant relationship between trade in telecommunication services and growth for countries with income per capita below an endogenously determined threshold level, and no evidence of a significant relationship for countries above this threshold. 
In their study for 72 countries, Seabra - Galimberti (2012) find a positive and statistically significant effect of exports on growth. They emphasise that the positive effect of exports on growth is higher for countries with lower levels of human capital stock and lower shares of exports to GDP. Moreover, this effect becomes lower when the export share rises, where the level of human capital starts to play a more important role conditioning the enhancement of the exports effect on growth. Lastly, Falvey et al. (2013) use data of 58 developing countries and present evidence on the fact that trade liberalisation has a positive direct effect on growth where significant thresholds emerge for the share of investment, government expenditures, and black market premium. Huang - Chang (2014) make allowances for the role of the financial system on the nexus of trade openness and GDP growth. With panel data for 46 countries over the period of 1983-2007, they observe significant effects of the financial system, and find that stock market development measures such as total value traded of stock market to GDP and stock market capitalisation to GDP ratio are suitable for being selected as threshold variables.

In sum, studies that consider the possible non-linearity in trade-growth nexus usually employ initial GDP per capita, export share, and investment rate as threshold variables. However, less attention has been paid to the effect of financial deepening in trade-growth relationships.

\section{DATA AND METHODOLOGY}

We employ threshold regression techniques to examine whether the relationship between international trade and growth depends on a third variable, namely on financial deepening. If the true relationship between trade and growth is nonmonotonic, models that do not allow for this non-monotonicity would lead to a downward bias in the estimated relationship between international trade and economic growth (Foster 2006). For these peculiarities, Hansen's (1999) threshold regression techniques have been employed in our study.

Our work includes many steps. We first examine a standard growth model applying panel data methods to annual data for the panel of $11 \mathrm{CEE}$ economies over the period of 1995-2012. After finding a significant positive relationship between trade and per capita GDP growth, we search for the non-linear relationship, namely the changing role of international trade, conditional on the level of related variables. Our thresholds in the trade-growth relationship are based on the level of financial deepening. We use three common measures of financial deepening. One of them is the share of broad money (M2) within GDP. M2 as a percentage of GDP has become a standard measure of financial depth and an indicator of the 
overall size of financial intermediary activity in cross-country studies (King - Levine 1993; Rousseau - Wacthel 2005). Another indicator we use is the claims on the private sector (annual growth as a percentage of M2), which is also a standard indicator in pioneering works (King - Levine 1993; Rajan - Zingales 1998).

Another standard financial deepening indicator is the rate of the growth of domestic credits to the private sector. It is a well-known fact that as a consequence of less developed capital markets, the financial system of CEE economies are mostly bank-based, which makes bank credits the main source of external financing (Egert et al. 2016). The ratio of investment to domestic private credits is also employed as a threshold variable, where the increasing volume of credits delivered to finance investments makes this ratio higher. The description and the source of the data are presented in Table 1.

In the first step, the structural equation of interest is specified as follows:

$$
y_{i t}=\mu_{i}+\alpha X_{i t}+\beta O P E N_{i t}+e_{i t}, e_{i t} \approx \operatorname{iid}\left(0, \sigma^{2}\right),
$$

where $X$ includes the control variables of the annual rate of population growth, share of investment in GDP (i.e. gross capital formation as a share of GDP), and public spending on education as a percentage of GDP.

In the second stage, Hansen's (1999) advanced panel threshold regression model enables us not only to test the relationship between international trade and growth, but also to calculate some threshold levels for particular variables; this will differentiate our sample into sub-samples endogenously. Hansen's (1999)

Table 1. Data description

\begin{tabular}{|c|c|c|}
\hline Variable & Description & Source \\
\hline Grgdp & Annual growth rate of GDP per capita & WDI \\
\hline Exp & Exports of goods and services as \% of GDP & WDI \\
\hline Imp & Imports of goods and services as $\%$ of GDP & WDI \\
\hline Open & $\begin{array}{l}\text { Openness measured by the ratio of imports plus } \\
\text { exports to GDP }\end{array}$ & WDI \\
\hline Inv & Gross Capital Formation as \% of GDP & WDI \\
\hline Pop & Annual growth rate of population & WDI \\
\hline Edu & Public spending on education ( $\%$ of GDP) & WDI \\
\hline M2/GDP & Money and quasi money (M2) as \% of GDP & WDI \\
\hline Claims & $\begin{array}{l}\text { Claims on the private sector } \\
\text { (annual growth as \% of M2) }\end{array}$ & WDI \\
\hline Creditgr & $\begin{array}{l}\text { Annual growth rate of domestic credits to private } \\
\text { sector as } \% \text { of GDP }\end{array}$ & $\begin{array}{l}\text { WDI, } \\
\text { Own calculations }\end{array}$ \\
\hline investment/credit & Ratio of investment to domestic private credits & $\begin{array}{l}\text { WDI, } \\
\text { Own calculations }\end{array}$ \\
\hline
\end{tabular}


model is an extension of the traditional least squares estimation method allowing endogenously determined threshold values. Ensuring that the variables of interest are stationary, ${ }^{2}$ we estimate the panel threshold regression models. In estimating the panel threshold regression model, we first investigate whether there is a threshold level of the variable of interest. Setting the null hypothesis against this threshold effect, if we cannot reject this null hypothesis, we conclude that the threshold does not exist.

However, the existence of the nuisance parameter leads this test statistics to follow an on-standard distribution, which is referred to as Davies' Problem, namely the issue of deriving variance and standard errors for estimated threshold parameters $(1977,1987)$. Thus, Hansen (1999) suggests bootstrapping methods in order to make statistical inferences about estimated thresholds. These methods utilise simulation techniques to calculate the asymptotic distribution of test statistics and test the significance of the threshold effect. When the null hypothesis regarding the threshold effect does not hold, it means that there exists a threshold level of the chosen threshold variable. Chan (1993) and Hansen (2000) demonstrate that the ordinary least squares (OLS) estimation of the threshold is super-consistent, and they derive the asymptotic distribution of the estimated threshold. However, since this distribution is non-standard because of the nuisance parameter, Hansen (1999) suggests a likelihood ratio test defined by a sup-Wald statistic in order to obtain the valid p-values. In the estimation of the panel threshold model, Hansen (1999) uses a two-stage OLS methodology. In the first stage, the sum of the squared errors (SSE) is computed separately for any given threshold $(\lambda)$. In the second stage, the estimation of the threshold $(\bar{\lambda})$ is obtained by minimising the sum of the squares and then the coefficients of each regime are estimated using this endogenously estimated threshold value.

\section{The model}

Let $y_{i t}$ define the growth of real GDP per capita, $O P E N_{i t}$ define one of the trade variables as exports of goods and services as a percentage of GDP (exp), imports of goods and services as a percentage of GDP (imp), and openness measured by

2 In order to avoid the spurious regression problem, all variables considered in the model must be stationary. Therefore, before using the panel threshold regression model, we proceed with panel unit root tests. We employ two different panel-based unit root tests, the Levin-Lin-Chu ADF (Levin et al. 2002), and the IPS ADF (Im et al. 2003), to examine the null of a unit root of all of the variables chosen in the models. We find that all the variables have stationary characteristics since the nulls of the unit root are rejected. Results of the panel unit root tests are available upon request. 
the ratio of imports plus exports to GDP (open), respectively. $X_{i t}$ represents the set of control variables, including gross capital formation as a percentage of GDP, the annual rate of population growth, and public expenditures on education as a percentage of GDP. We construct our single threshold model for growth-trade relationship as follows:

$$
\begin{gathered}
y_{i t}=\mu_{i}+\alpha X_{i t}+\beta O P E N_{i t}+e_{i t}, e_{i t} \sim \operatorname{iid}\left(0, \sigma^{2}\right) \\
y_{i t}=\left\{\begin{array}{l}
\mu_{i}+\alpha X_{i t}+\beta_{1} O P E N_{i t}+e_{i t}, F D_{i t} \leq \lambda \\
\mu_{i}+a \ln X_{i t}+\beta_{2} O P E N_{i t}+e_{i t}, F D_{i t}>\lambda \\
\alpha=\left(\alpha_{1}, \alpha_{2}, \alpha_{3}\right)^{\prime} X_{i t}=\left(i n v_{i t}, \text { pop }_{i t}, e d u_{i t}\right)^{\prime}
\end{array}\right.
\end{gathered}
$$

where $\left\{y_{i t}, X_{i t}, O P E N_{i t}, F D_{i t}: 1 \leq i \leq n, 1 \leq t \leq T\right\}$ is an observed panel data set regarding our sample CEE countries. $F D_{i t}$ is the threshold variable, and $\lambda$ is the specific estimated threshold value. $\mu_{i}$ is the fixed effect, representing the heterogeneity of countries having different levels of financial deepening; the error term $e_{i t}$ is assumed to be independent and identically distributed with mean zero and finite variance.

The threshold regression model (1) can be rewritten as:

$$
y_{i t}=\mu_{i}+\alpha X_{i t}+\beta_{1} O P E N_{i t} I\left(F D_{i t} \leq \lambda\right)+\beta_{2} O P E N_{i t} I\left(F D_{i t}>\lambda\right)+e_{i t},
$$

where $I$ represents the indicator function. This equation can also be rewritten as:

$$
\begin{aligned}
& y_{i t}=\mu_{i}+\alpha^{\prime} X_{i t}+\beta^{\prime} \operatorname{OPEN}_{i t}(\lambda)+e_{i t}, \beta=\left(\beta_{1}, \beta_{2}\right)^{\prime} \\
& y_{i t}=\mu_{i}+\left[\alpha^{\prime}, \beta^{\prime}\right]\left[\begin{array}{c}
X_{i t} \\
\operatorname{OPEN}_{i t}(\lambda)
\end{array}\right]+e_{i t} \\
& y_{i t}=\mu_{i}+\theta^{\prime} h_{i t}(\lambda)+e_{i t} \\
& \operatorname{OPEN}_{i t}(\lambda)=\left[\begin{array}{c}
\operatorname{OPEN}_{i t} I\left(F D_{i t} \leq \lambda\right) \\
\operatorname{OPEN}_{i t} I\left(F D_{i t}>\lambda\right)
\end{array}\right]
\end{aligned}
$$

where $\theta=\left(\alpha^{\prime}, \beta^{\prime}\right)^{\prime}$ and $h_{i t}\left(X_{i t}^{\prime}, \operatorname{OPEN}_{i t}(\lambda)^{\prime}\right)^{\prime}$.

In this configuration, the slope parameters $\left(\beta_{1}, \beta_{2}\right)$, identifying the impact of trade on growth, will be differentiated between the regimes determined upon the threshold level $(\lambda)$ regarding financial depth. In other words, the observations are divided into two regimes depending on whether the threshold variable $\left(F D_{i t}\right)$ is smaller or greater than the threshold value $(\lambda)$. 


\section{Estimations}

Taking the growth-trade model (3) as a reference, we take the average of the equation over time as in linear panel estimation models and derive the following:

$$
\bar{y}_{i}=\mu_{i}+\Theta^{\prime} \bar{h}_{i}(\lambda)+\bar{e}_{i},
$$

where,

$$
\bar{y}_{i}=T^{-1} \sum_{t=1}^{T} w_{i t}, \quad \bar{h}_{i}=T^{-1} \sum_{t=1}^{T} \bar{h}_{i t}, \quad \bar{e}_{i}=T^{-1} \sum_{t=1}^{T} e_{i t}
$$

and when we proceed taking the difference between equations (3) and (5), we obtain:

$$
y_{i t}^{*}=\theta^{\prime} h_{i t}^{*}(\lambda)+e_{i t}^{*}
$$

where $y_{i t}^{*}=y_{i t}-\bar{y}_{i}, h_{i t}^{*}(\lambda)=h_{i t}(\lambda)-\bar{h}_{i}(\lambda), e_{i t}^{*}=e_{i t}-\bar{e}_{i}$.

Let

$$
y_{1}^{*}=\left[\begin{array}{c}
y_{i 2}^{*} \\
\cdot \\
\cdot \\
\cdot \\
y_{i t}^{*}
\end{array}\right], \quad h_{i}^{*}(\gamma)=\left[\begin{array}{c}
h_{i 2}^{*}(\lambda) \\
\cdot \\
\cdot \\
\cdot \\
h_{i t}^{*}(\lambda)
\end{array}\right], \quad \varepsilon_{i}^{*}=\left[\begin{array}{c}
e_{i 2}^{*} \\
\cdot \\
\cdot \\
\cdot \\
e_{i t}^{*}
\end{array}\right] \text {. }
$$

We denote the stacked data and errors for an individual, with one time period deleted. Then we let $G^{*}, H^{*}$, and $\varepsilon^{*}$ denote the data stacked over all individuals:

$$
G^{*}=\left[\begin{array}{c}
y_{1}^{*} \\
\cdot \\
\cdot \\
\cdot \\
y_{n}^{*}
\end{array}\right], H^{*}(\lambda)=\left[\begin{array}{c}
h_{1}^{*}(\lambda) \\
\cdot \\
\cdot \\
\cdot \\
h_{i t}^{*}(\lambda)
\end{array}\right], \varepsilon^{*}=\left[\begin{array}{c}
e_{1}^{*} \\
\cdot \\
\cdot \\
\cdot \\
e_{n}^{*}
\end{array}\right]
$$

Using this notation (6) is equivalent to:

$$
G_{i t}^{*}=\theta^{\prime} H_{i t}^{*}(\lambda)+\varepsilon_{i t}^{*} .
$$

Equation (7) is our major estimation model for the threshold effect. For any given $\lambda$, the slope coefficients can be estimated using OLS. That is:

$$
\hat{\theta}(\lambda)=\left(H^{*}(\lambda)^{\prime} H^{*}(\lambda)\right)^{-1} H^{*}(\lambda)^{\prime} G^{*} .
$$


The vector of the residuals is expressed as:

$$
\widehat{\varepsilon}^{*}(\lambda)=G^{*}-H^{*}(\lambda) \hat{\theta}(\lambda) .
$$

The sum of squared errors ( $\mathrm{SSE})$ is:

$$
\operatorname{SSE}_{1}(\lambda)=\widehat{\varepsilon}^{*}(\lambda) \widehat{\varepsilon}^{*}(\lambda)^{\prime}=G^{*^{\prime}}\left(I-H^{*}(\lambda)^{\prime}\left(H^{*}(\lambda)^{\prime} H^{*}(\lambda)\right)^{-1} H^{*}(\lambda)^{\prime}\right) G^{*} .
$$

Chan (1993) and Hansen (1999) recommend estimating $\lambda$ using the least squares. Thus, we minimise the concentrated SSEs (11) and get the least square estimator of $\lambda$ as:

$$
\hat{\lambda}=\underset{\lambda}{\operatorname{argmin}} S S E_{1}(\lambda) .
$$

Once the estimated threshold value, $\hat{\lambda}$ is obtained, the slope coefficients estimate is $\hat{\theta}=\hat{\theta}(\lambda)$, the residual vector is $\widehat{\varepsilon}^{*}=\widehat{\varepsilon}^{*}(\lambda)$, and the estimator of residual variance is,

$$
I \widehat{f}^{*}=\frac{1}{n(T-1)} \widehat{\varepsilon}^{* \prime} \widehat{\varepsilon}^{*}=\frac{1}{n(T-1)} \operatorname{SSE}_{1}(\widehat{\lambda}),
$$

where $n$ is the number of countries in the sample and $T$ is the number of years included.

\section{Testing for a threshold}

In this study we hypothesise that there is a threshold effect between economic growth and trade. After estimating the threshold parameters $(\bar{\lambda})$ for our model, we utilise likelihood ratio tests in order to check for the statistical significance of the estimated threshold parameters. In order to obtain the p-values regarding these tests, bootstrapping methods offered by Hansen $(1996,1999)$ are utilised. Accordingly, $F(\lambda)$ shows the bootstrapping value of a likelihood ratio test and $\xi$ defines the conditional mean of $\stackrel{I}{F}(\lambda)$ where $\stackrel{I}{F}(\lambda)>F(\lambda)$. This $\xi$ is the estimated bootstrapping value of the asymptotic p-value belonging to the likelihood ratio test regarding the threshold parameter under the null hypothesis of $H_{0}: \beta_{1}=\beta_{2}$. If $H_{0}$ can be rejected, the existence of the threshold effect is approved.

In the next stage, confidence regions for the threshold parameters are computed. Chan (1993) and Hansen (1999) showed that when the threshold effect exists, $\widehat{\lambda}$ is consistent. Hansen (1999) suggested that the best way to formulate a confidence interval for $\lambda$ is to form a "no-rejection region" using the likelihood 
ratio statistics on $\lambda$. While he constructs $H_{0}: \hat{\lambda}=\lambda_{0}$, the LR test for this null hypothesis is computed as $L R_{1}(\lambda)=\left(\operatorname{SSE}_{1}(\lambda)-\operatorname{SSE}_{1}(\hat{\lambda})\right) / \overline{I f}{ }^{2}$. When $L R_{1}(\lambda)$ is large enough and the p-value is beyond the confidence interval, $H_{0}$ is rejected. Furthermore, under $H_{0}$ and some special assumptions ${ }^{3} n \rightarrow \infty, L R_{1}(\gamma) \rightarrow d \xi$; where $\xi$ is a random variable by the distribution function $P(\xi \leq x)=\left(1-\exp \left(-\frac{x}{2}\right)\right)^{2}$. This function can be rewritten as $c(\alpha)=-2 \log (1-\sqrt{1-\alpha})$. From here, it is easy to calculate the critical values for a given asymptotic level $\alpha$, if $L R_{1}>c(\alpha)$, then $H_{0}: \bar{\lambda}=\lambda_{0}$ is rejected.

\section{EMPIRICAL RESULTS}

At the initial stage, GDP growth equations for each trade variable were estimated by the fixed effects panel data estimation methodology without threshold variables (Table 2). According to the first group of estimations, overall the most common determinants of growth, i.e. investment rate (inv) and population growth ( $p o p)$, were found to be significant, with population growth showing some sensibility of sample choice. The coefficient on population growth was expected to be negative and significant, while population growth constitutes an important restriction on economic growth for underdeveloped countries (Seabra - Galimberti 2012). However, in the existing literature, both positive and negative coefficients on population growth were estimated, with Levine - Renelt (1992) finding the coefficient on this variable to be "fragile".

Including the quadratic term on our human capital variable, we found a negative coefficient on $E d u$ and a positive coefficient on $E d u \_s q$; this provides evidence that, for countries with low levels of education, there is a negative relationship between education and growth, whereas for countries with higher levels of education, the relationship turns to be positive.

A negative coefficient on the human capital variable has often been encountered in the empirical growth literature. Pritchett (2001) mentions some reasons for the existence of this negative relationship. He argues that in poor countries, it is usually the case that educated people are employed in rent-seeking and directly unproductive economic activity or in the public sector, which can restrain growth by drawing educated people away from the most productive sectors. Given that both education and its quadratic term are found to be significant, we include them in our threshold regressions. All our trade variables appear to have a significant effect on growth, confirming that international trade is significantly related to

3 Refer to Hansen (1999), Appendices 1-8. 
Table 2. Fixed effect regressions

\begin{tabular}{lccc}
\hline & 1 & 2 & 3 \\
\hline Inv & $0.558^{* * *}$ & $0.508^{* * *}$ & $0.515^{* * *}$ \\
Pop & $(0.069)$ & $(0.068)$ & $(0.067)$ \\
& $-2.5^{* * *}$ & $-2.466^{* * *}$ & $-2.497^{* * *}$ \\
Edu & $(0.6)$ & $(0.602)$ & $(0.604)$ \\
& $-7.89^{* *}$ & $-6.638^{*}$ & $-6.919^{* *}$ \\
Edu_sq & $(3.86)$ & $(3.814)$ & $(3.844)$ \\
& $0.679^{*}$ & $0.543^{*}$ & $0.569^{*}$ \\
Exp & $(0.406)$ & $(0.301)$ & $(0.304)$ \\
& $0.085^{* * *}$ & & \\
Imp & $(0.034)$ & & \\
& & $0.083^{* *}$ & \\
Open & & $(0.037)$ & \\
& & & $0.034^{* *}$ \\
Num.of Obs. & 198 & & $(0.018)$ \\
F Stat. & 16.76 & 198 & 16.02 \\
R-square & 0.32 & 0.31 & 0.31 \\
\hline
\end{tabular}

Notes: White heteroscedasticity consistent standard errors are in parentheses. $* * *, * *$ and $*$ indicate statistical significance at the 1,5 , and $10 \%$ levels, respectively.

growth in our sample of CEE economies. Finally, as the significance and size of coefficients are higher for exports than imports, we may conclude that the growth in selected countries is export-led.

After estimating the linear fixed effects model, we next estimate threshold models for each trade variable in order to investigate the likely non-linear impact of our financial deepening indicators on growth-trade relationship. The threshold models assume that economic growth and international trade have a non-linear relationship, conditioning on some threshold levels for financial indicators. Regarding this asymmetric relationship, if the existence of a single threshold effect is approved, we also test for a second threshold effect. ${ }^{4}$ Accordingly, structural models of the estimation of growth-trade relationship for the double and single threshold effects become:

$$
y_{i t}=\mu_{i}+\alpha X_{i t}+\beta_{1} O P E N_{i t} I\left(F D_{i t} \leq \lambda_{1}\right)+\beta_{2} O P E N_{i t} I\left(F D_{i t}<\lambda_{2}\right)+e_{i t}
$$

4 The threshold model can easily be extended for two or more thresholds. The estimation of these multiple thresholds follows the same procedures as in the estimation of a single threshold model. For further details, see Hansen (1999). 
Table 3. Threshold regressions: Exports

\begin{tabular}{lcccc}
\hline & M2/GDP & Claims & Creditgr & Investment/Credit \\
\hline Inv & $0.604^{* * *}$ & $0.597^{* * *}$ & $0.586^{* * *}$ & $0.558^{* * *}$ \\
& $(0.072)$ & $(0.08)$ & $(0.079)$ & $(0.06)$ \\
Pop & $-2.57^{* * *}$ & $-2.8^{* * *}$ & $-2.548^{* * *}$ & $-2.526^{* * *}$ \\
& $(0.507)$ & $(0.536)$ & $(0.603)$ & $(0.541)$ \\
Edu & $-7.29^{* *}$ & $-7.34^{* *}$ & $-7.49^{* *}$ & $-7.57^{* *}$ \\
& $(3.66)$ & $(3.06)$ & $(3.42)$ & $(3.55)$ \\
Edu_sq & $0.573^{*}$ & $0.566^{*}$ & $0.546^{*}$ & $0.567^{*}$ \\
& $(0.306)$ & $(0.332)$ & $(0.321)$ & $(0.304)$ \\
Exp (FD $\leq \lambda)$ & $0.27^{* * *}$ & - & $0.143^{* * *}$ & $0.079^{* *}$ \\
& $(0.05)$ & & $(0.038)$ & $(0.034)$ \\
Exp (FD $>\lambda)$ & $0.167^{* * *}$ & - & $0.193^{* * *}$ & $0.175^{* * *}$ \\
& $(0.034)$ & & $(0.04)$ & $(0.039)$ \\
Threshold & $37.29^{* * *}$ & 10.96 & $0.108^{*}$ & $0.323^{* * *}$ \\
p-value & 0.000 & 0.160 & 0.100 & 0.033 \\
Confidence Region & $(35.85,37.29)$ & - & $(0.09,0.20)$ & $(0.22,0.38)$ \\
F Stat. & 53.17 & 12.77 & 16.75 & 47.4 \\
\hline
\end{tabular}

Notes: F-statistics and p-values are obtained by 300 times repetition of the bootstrap procedure. White heteroscedasticity consistent standard errors are in parentheses. $* * *, * *$, and $*$ indicate statistical significance at the 1,5 , and $10 \%$ levels, respectively.

respectively.

We first estimate the structural model, testing the non-linear relationship between growth and exports as a percentage of GDP, where we employ various financial deepening indicators as threshold variables. Table 3 presents the coefficient estimates together with the tests for the threshold effects regarding the growth-exports relationship. Regardless of the threshold variable employed, the size, sign, and significance of the control variables in each model are quite stable. As for threshold results, we find one statistically significant threshold level for each financial indicator, ${ }^{5}$ except for claims on the private sector. These thresholds split our sample into two regimes where the impact of exports on economic growth changes. In other words, the existence of these thresholds indicates the rejection of the null hypothesis that the structural model could be estimated linearly.

Considering the threshold on the M2/GDP, we find a significant threshold value of 37.28 at the $29^{\text {th }}$ percentile of the distribution. Estimates indicate that the positive effect of exports on GDP per capita growth becomes higher below the threshold level of M2/GDP; i.e. for countries in the low level of M2/GDP

5 We do not report the test results for the second threshold effects since we cannot find any evidence of it in any model. 
Table 4. Threshold regressions: Imports

\begin{tabular}{lcccc}
\hline & M2/GDP & Claims & Creditgr & Investment/Credit \\
\hline Inv & $0.52^{* * *}$ & $0.583^{* * *}$ & $0.53^{* * *}$ & $0.509^{* * *}$ \\
& $(0.071)$ & $(0.087)$ & $(0.065)$ & $(0.069)$ \\
Pop & $-2.69^{* * *}$ & $-2.74^{* * *}$ & $-2.52^{* * *}$ & $-2.6^{* * *}$ \\
& $(0.455)$ & $(0.563)$ & $(0.544)$ & $(0.487)$ \\
Edu & $-7.02^{* *}$ & $-7.71^{* *}$ & $-7.19^{* *}$ & $-7.37^{* *}$ \\
& $(3.83)$ & $(3.92)$ & $(3.67)$ & $(3.24)$ \\
Edu_sq & $0.56^{*}$ & $0.559^{*}$ & $0.542^{*}$ & $0.555^{*}$ \\
& $(0.323)$ & $(0.378)$ & $(0.31)$ & $(0.328)$ \\
Imp (FD $\leq \lambda)$ & $0.216^{* * *}$ & 0.032 & $0.145^{* * *}$ & -0.116 \\
& $(0.046)$ & $(0.030)$ & $(0.044)$ & $(0.08)$ \\
Imp (FD> $\lambda)$ & $0.134^{* * *}$ & $0.070^{* * *}$ & $0.189^{* * *}$ & $0.088^{* * *}$ \\
& $(0.04)$ & $(0.030)$ & $(0.046)$ & $(0.033)$ \\
Threshold & $37.29^{* * *}$ & $10.96^{*}$ & $0.108^{*}$ & $0.22^{* * *}$ \\
p-value & 0.000 & 0.086 & 0.09 & 0.003 \\
Confidence Region & $(35.47,37.29)$ & $(9.82,12.06)$ & $(0.09,0.15)$ & $(0.220,0.223)$ \\
F Stat. & 42.31 & 20.56 & 19.77 & 54.69 \\
\hline
\end{tabular}

Notes: F-statistics and p-values are obtained by 300 times repetition of the bootstrap procedure. White heteroscedasticity consistent standard errors are in parentheses. $* * *, * *$, and $*$ indicate statistical significance at the 1,5 , and $10 \%$ levels, respectively.

regime, there exists a larger positive effect of exports on growth. With regard to the threshold based on the credit growth, we find a significant threshold at the $65^{\text {th }}$ percentile. This result suggests that the growth-promoting effects of increased exports are larger above the threshold, i.e. the countries in the upper regime benefit significantly more from exports. The estimated coefficient over the threshold is approximately 35 percent higher than that of below the threshold.

The last threshold variable, investment to credit ratio, provides a stronger threshold effect for the growth-exports relationship compared to the previous ones. This last model constitutes a 121 percent higher coefficient of exports than that of below the threshold level of 0.323 estimated at the $15^{\text {th }}$ percentile, i.e. towards the lower end of the distribution. On the other hand, the results could be perceived as being somewhat contradictory since a weaker positive relationship is found above the threshold value when we use the M2/GDP as a proxy for financial deepening. However, this result could reflect the impact of developments in the credit market on the M2/GDP variable, which is a broader indicator showing the intensity in the banking sector rather than other variables. As Kiss et al. (2006) approved, any credit expansion, thus financial deepening beyond a certain growth rate, should be considered as excessive in the sense that it leads to macroeconomic imbalances such as a decline in export growth accompanied by a fall in GDP, which weakens the promoting effects of exports on economic growth. 
Table 5. Threshold regressions: Openness

\begin{tabular}{lcccc}
\hline & M2/GDP & Claims & Creditgr & Investment/Credit \\
\hline Inv & $0.574^{* * *}$ & $0.567^{* * *}$ & $0.494^{* * *}$ & $0.512^{* * *}$ \\
& $(0.079)$ & $(0.097)$ & $(0.085)$ & $(0.092)$ \\
Pop & $-2.71^{* * *}$ & $-2.81^{* * *}$ & $-2.80^{* * *}$ & $-2.54^{* * *}$ \\
& $(0.459)$ & $(0.549)$ & $(0.570)$ & $(0.492)$ \\
Edu & $-7.29^{* *}$ & $-7.68^{* *}$ & $-7.11^{* *}$ & $-7.21^{* *}$ \\
& $(3.63)$ & $(3.88)$ & $(3.42)$ & $(3.30)$ \\
Edu_sq & $0.558^{*}$ & $0.56^{*}$ & $0.539^{* *}$ & $0.553^{*}$ \\
& $(0.301)$ & $(0.369)$ & $(0.305)$ & $(0.309)$ \\
Open (FD $\leq \lambda)$ & $0.119^{* * *}$ & - & $0.072^{* * *}$ & -0.058 \\
& $(0.024)$ & & $(0.021)$ & $(0.043)$ \\
Open (FD> $\lambda)$ & $0.074^{* * *}$ & - & $0.095^{* * *}$ & $0.041^{* * *}$ \\
& $(0.020)$ & & $(0.022)$ & $(0.016)$ \\
Threshold & $37.29 * * *$ & 10.96 & $0.108^{*}$ & $0.22^{* * *}$ \\
p-value & 0.000 & 0.153 & 0.077 & 0.030 \\
Confidence Region & $(35.17,37.29)$ & - & $(0.092,0.187)$ & $(0.21,0.246)$ \\
\hline F Stat. & 46.43 & 15.46 & 16.35 & 49.81 \\
\hline
\end{tabular}

Notes: F-statistics and p-values are obtained by 300 times repetition of the bootstrap procedure. White heteroscedasticity consistent standard errors are in parentheses. $* * *, * *$, and * indicate statistical significance at the 1,5 , and $10 \%$ levels, respectively.

The threshold estimation results from the growth-import relationship are reported in Table 4. For the case of imports, all the threshold variables of financial indicators are statistically significant. Regarding the threshold model of M2/GDP, the size of the influence of imports on GDP per capita growth is larger in the lower regime and is similar to the case for the growth-export nexus. The threshold effect for credit growth also reflects the same finding as with the previous regression for the relationship of growth and exports. Contrary to the previous regression with claims on private sector as a threshold variable, we find a statistically significant threshold level of 10.96 , estimated at the $33^{\text {rd }}$ percentile of the distribution. Below this threshold for claims on the private sector we cannot find a significant effect of imports on GDP per capita growth, while over the threshold, this effect turns to be positively significant.

The final model of investment to credit ratio again tells a slightly different story than the previous results in Table 3. There exists a positive and significant relationship between imports and growth in the upper regime, whereas we find a negative and insignificant coefficient in the lower regime that is split by the threshold value of 0.22 , estimated at the $10^{\text {th }}$ percentile. This strong threshold effect indicates that an expanding volume of credits delivered to finance investments could be an alert for a credit boom, which has been experienced by the CEE economies in the 2000s. As Bakker - Gulde (2010) state, countries with 
rapid credit growth had a rise in imports via domestic demand expansion that has led to growing economies through current account deficits.

Finally, we report the results from the threshold regressions on the growthopenness relationship in Table 5. These results are similar to those from the regressions on growth-export nexus, i.e. we find one statistically significant threshold for each financial indicator, except for claims on the private sector, splitting our sample into two sub-regimes where the impact of openness to trade on economic growth differentiates. The threshold model for the credit growth variable suggests that the growth-promoting effect of an increased share of total trade is lower below the threshold level, while for the investment/credit ratio this effect turns to be insignificant below the threshold. Similarly to the previous regressions, we find a weaker positive relationship above the threshold level when we use the M2/GDP as a proxy for financial deepening.

\section{CONCLUSION}

Theory and policymakers suggest that international trade has positive effects on the growth rate of economies. Although a vast literature has illustrated that open or more liberalised economies grow faster, less attention has been paid to the channels that serve the growth-promoting effects of trade. In this paper, we employed threshold regression techniques to explore the potential non-linearity of the relationships in question, with a special focus on the financial deepening level of selected CEE countries.

We followed a standard growth model by using population growth, investment ratio, and share of public expenditures on education as control variables in order to test whether there is a significant relationship between international trade and growth. Following Dowrick-Golley (2004) and Dufrenot et al. (2010), we employed exports and imports as a share of GDP as well as the share of total trade value (trade openness) in our specifications. The results of our basic specification suggest that there is a positive and significant relationship for each international trade indicator. In addition, the estimated coefficients of our control variables, which are common determinants of growth, are found to be consistent with the literature.

In order to explore the potential non-linearity in trade-growth relationships, we estimated threshold models for each trade variable following Hansen (1999). We employed broad money as a share of GDP, annual growth rate of claims on the private sector as a share of M2, the growth rate of domestic credits to the private sector, and the ratio of investment to private credits as threshold variables. When 
we estimated the structural models to test the non-linear relationship in growthexports and growth-openness, we found one statistically significant threshold level for each financial indicator, except for claims on the private sector. These thresholds separated our sample of CEE economies into two regimes where the impact of trade on economic growth differentiates.

Regarding the credit growth and investment/credit ratio as thresholds, the countries in the upper regime benefit significantly more from trade. However, the result is contradictory when we use broad money as a share of GDP, which implies that expansion beyond a certain rate causes imbalances and weakens the effectiveness of trade. The threshold estimation results from the growth-import relationship indicate consistent findings with the other models of trade. Contrary to the other findings, we find a statistically significant threshold level for claims on the private sector. Below this threshold value, we cannot find a significant effect of imports on GDP per capita growth, while over the threshold, this effect turns to be positively significant.

To sum up, our results indicate the non-linearity of the adjustments involved in the growth-promoting effects of trade and that financial deepening is an important channel. Whilst there might be some other channels in this context, considering the non-linearities they create would be worthwhile and a fruitful area for future research.

\section{REFERENCES}

Acemoğlu, D. (2007): Introduction to Modern Economic Growth. Princeton: Massachusetts Institute of Technology.

Awokuse, T. (2007): Causality between Exports, Imports, and Economic Growth: Evidence from Transition Economies. Economics Letters, 94(3): 389-395.

Bakker B. B. - Gulde, A. M. (2010): The Credit Boom in the EU New Member States: Bad Luck or Bad Policies. IMF Working Paper, WP/10/30.

Caporela, G. M. - Rault, C. - Sova, R. - Sova, A. (2015): Financial Development and Economic Growth: Evidence from Ten New EU Members. Brunel University Economics and Finance Working Paper Series, No. 09-37.

Carp, L. - Popa, D. (2013): The Relationship between Foreign Direct Investment, Trade and Economic Growth in Bulgaria and Romania under the Impact of the Globalization. Proceedings in Conference of Informatics and Management Sciences, 2(1): 168-173.

Chan, K. S. (1993): Consistency and Limiting Distribution of the Least Squares Estimator of a Threshold Autoregressive Model. Annals of Statistics, 21: 520-533.

Davies, R. B. (1977): Hypothesis Testing When a Nuisance Parameter is Present Only under the Alternative. Biometrika, 64: 247-254.

Davies, R. B. (1987): Hypothesis Testing When a Nuisance Parameter is Present Only under the Alternative. Biometrika, 74: 33-43. 
Dean, J. - Desai, S. - Riedel, J. (1994): Trade Policy Reform in Developing Countries since 1985: A Review of the Evidence. World Bank Discussion Papers, No. 267.

De Loecker, J. (2007): Do Exports Generate Higher Productivity? Evidence from Slovenia. Journal of International Economics, 73(1): 69-98.

Dowrick, S. - Golley, J. (2004): Trade Opennes and Growth: Who Benefits? Oxford Review of Policy, 20(1): 38-56.

Dufrenot, G. - Mignon, V. - Tsangarides, C. (2010): The Trade-Growth Nexus in the Developing Countries: A Quantile Regression Approach. Review of World Economics, 146(4): 731-761.

Edwards, S. (1998): Openness, Productivity and Growth: What do We Really Know? Economic Journal, 108(447): 383-398.

Egert, B. - Backe, P. - Zumer, T. (2016): Private-Sector Credit in Central \& Eastern Europe: New (Over) Shooting Stars? William Davidson Institute Working Paper, No. 852.

Falvey, R. - Foster-McGregor, N. - Khalid, A. (2013): Trade Liberalization and Growth: A Threshold Exploration. Journal of the Asia Pacific Economy, 18(2): 230-252.

Ferreira-Lopes, A. - Neves Sequeira, T. (2014): The Dynamics of the Trade Balance and the Terms of Trade in Central and Eastern European Countries. Acta Oeconomica, 64(1): 51-71.

Fitzova, H. - Zidek, L. (2015): Impact of Trade on Economic Growth in the Czech and Slovak Republics. Economics and Sociology, 8(2): 36-50.

Foster, N. (2006): Exports, Growth and Threshold Effects in Africa. The Journal of Development Studies, 42(6): 1056-1074.

Fries, S. - Neven, D. J. - Seabright, P. - Taci, A. (2006): Market Entry, Privatization and Bank Performance in Transition. Economics of Transition, 14(4): 579-610.

Galimberti, J. K. (2009): Conditioned Export-Led Growth Hypothesis: A Panel Threshold Regressions Approach. Munich Personal RePEc Archieve Working Paper, No.13417.

Greenaway, D. - Morgan, W. - Wright, P. (2002): Trade Liberalization and Growth in Developing Countries. Journal of Development Economics, 67(1): 229-244.

Halpern, L. (2013): Trade and Firms in Transition. In: Hare, P. - Turley, G. (eds): Handbook of the Economics and Political Economy of Transition. London: Routledge. pp. 275-283.

Hansen, B. E. (1996): Inference When a Nuisance Parameter is Not Identified under the Null Hypothesis. Econometrica, 64(2): 413-430.

Hansen, B. E. (1999): Threshold Effects in Non-Dynamic Panels: Estimation, Testing and Inference. Journal of Econometrics, 93(2): 345-368.

Hansen, B. E. (2000): Sample Splitting and Threshold Estimation. Econometrica, 68(3): 575-603.

Huang, L. C. - Chang, S. H. (2014): Revisit the Nexus of Trade Openness and GDP Growth: Does the Financial System Matter? The Journal of International Trade and Economic Development, 23(7): 1038-1058.

Im, K. S. - Pesaran, M. H. - Shin, Y. (2003): Testing for Unit Roots in Heterogeneous Panels. Journal of Econometrics, 115: 53-74.

Khoury, A. C. - Savvides, A. (2006): Openness in Services Trade and Economic Growth. Economic Letters, 92(2): 277-283.

King, R. G.- Levine, R. (1993): Finance and Growth: Schumpeter might be Right. Quarterly Journal of Economics, 108: 717-738.

Kiss, G. - Marton, N. - Vonák, B. (2006): Credit Growth in Central and Eastern Europe: Convergence or Boom. MNB Working Papers, 2006/10.

Levin, A. - Lin, C. F. - Chu, C. S. (2002): Unit Root in Panel Data: Asymptotic and Finite Sample Properties. Journal of Econometrics, 108(1): 1-24.

Levine, R. (2005): Finance and Growth: Theory and Evidence. In: Aghion, P. - Durlauf, S. (eds): Handbook of Economic Growth, Vol. 1, pp. 865-934. 
Levine, R. - Renelt, D. (1992): A Sensitivity Analysis of Cross Country Growth Regressions. American Economic Review, 82(4), 942-963.

Leyaro, V. - Morrissey, O. (2010): Trade and Growth: Is Sub-Saharan Africa Different? Credit Research Paper, No.10/04.

Michalopoulos, C. (2001): The Integration of Transition Economies into the World Trading System. Revue d'economie Financiere (English ed.), 6: 64-89.

Mikulic, D. - Nagyszombaty, A. G. (2015): Does International Trade Cause Regional Growth Differentials in Croatia? Proceedings of Rijeka School of Economics, 33(1): 81-102.

Nica, E. (2015): ICT Innovation, Internet Sustainability, and Economic Development. Journal of Self-Governance and Management Economics, 3(3): 24-29.

Popescu, G. H. (2015a): The Economic Value of the Industrial Internet of Things. Journal of SelfGovernance and Management Economics, 3(2): 86-91.

Popescu, G. H. (2015b): The Economic Value of Smart City Technology, Economics, Management, and Financial Markets, 10(4): 76-82.

Pritchett, L. (1996): Measuring Outward Orientation in LDCs: Can It be Done? Journal of Development Economics, 49(2): 307-335.

Pritchett, L. (2001): Where has All the Education Gone? World Bank Economic Review, 15: 367391.

Rajan, R. - Zingales, L. (1998): Which Capitalism? Lessons from the East Asian Crisis. Journal of Applied Corporate Finance, 11(3): 40-48.

Ricardo, D. (1951): The Works and Correspondence of David Ricardo. In: Sraffa, P. (ed.): On the Principals of Political Economy and Taxation. Cambridge: Cambridge University Press. pp. $1-447$.

Rousseau, P. L. - Wachtel, P. (2005): Economic Growth and Financial Depth: Is the Relationship Extinct Already? UNU-Wider Discussion Paper, No. 2005/10.

Sachs, J. - Warner, A. (1995): Economic Convergence and Economic Policies. National Bureau of Economic Research Working Paper, No. 5039.

Salinas, G. - Aksoy, A. (2012): Growth before and after Trade Liberalization. World Bank Policy Research Working Paper, No.4062.

Seabra, F. - Galimberti, J. K. (2012): Conditioned Export-Led Growth Hypothesis: A Panel Threshold Regressions Approach. Revistade Economia, 38(2): 7-24.

Thirlwall, A. P. (2000): Trade, Trade Liberalization and Economic Growth: Theory and Evidence. African Development Bank, Economic Research Papers, No. 63.

Wacziarg, R. - Welch, K. H. (2008): Trade Liberalization and Growth: New Evidence. World Bank Economic Review, 22(2): 187-231.

World Bank (1993): Report on Adjustment Lending III. Washington, D.C. 